\title{
1. Introduction: A viable pathway for enabling developing countries to attract foreign cleantech and build domestic cleantech innovation
}

Accelerating, encouraging and enabling innovation is critical for an effective, long-term global response to climate change and promoting economic growth and sustainable development. ${ }^{1}$ (Paris Agreement)

Climate change is a challenge, and the global community has set up ambitious goals for addressing it. In December 2015, 197 member countries of the United Nations Framework Convention for Climate Change ('UNFCCC') ${ }^{2}$ gathered in Paris. They negotiated the Paris Agreement, the latest milestone of the global community's efforts in addressing climate change. The Paris Agreement commits the global community to limit the average global temperature increase to less than $2^{\circ} \mathrm{C}$ above pre-industrial levels ${ }^{3}$ by the year 2100 and strive to bound the temperature increase to $1.5^{\circ} \mathrm{C}$ above pre-industrial levels. ${ }^{4}$ The Paris Agreement also sets the goal of net-zero greenhouse gas ('GHG') emissions

1 The Paris Agreement, art. 10.5; United Nations Framework Convention on Climate Change (2015), https://unfccc.int/sites/default/files/english_paris_agreement .pdf [hereinafter 'Paris Agreement']. Paris Agreement is an agreement under the United Nations Framework Convention on Climate Change (UNFCCC), drafted in December 2015, signed by 197 countries, became effective in November 2016. It is the largest global agreement on climate change up to date, focusing on climate change mitigation and adaptation, as well as the associated financing.

2 The UNFCCC is the main international treaty designed for addressing climate change. The goal of the UNFCCC is to stabilize 'greenhouse gas concentration in the atmosphere at a level that would prevent dangerous anthropogenic interference with the climate system'. The UNFCCC has become the main framework under which global negotiations on addressing climate change occur. See, What is the United Nations Framework Convention on Climate Change, UNFCCC (January 17, 2020), https://unfccc.int/process-and-meetings/the-convention/what-is-the-united-nations -framework-convention-on-climate-change [hereinafter the UNFCCC].

3 This means to above the global average temperature prior to the advent of the Industrial Revolution that occurred from 1750 to 1850.

4 Paris Agreement, supra note 1, art. 2.1.(a). 
in the second half of this century. ${ }^{5}$ The global community regards these goals as a vital accomplishment of the Paris Agreement. Without these aims and letting things continue unchecked, we run the risk of the annual average global temperature rising $5^{\circ} \mathrm{C}$ or more above pre-industrial levels by $2100 .^{6}$

Meanwhile, in 2015, the United Nations ('UN') adopted Agenda 2030 for global sustainable development. ${ }^{7}$ Agenda 2030 is a voluntary agreement calling for the global community to fulfil 17 sustainable development goals ('SDG's) by $2030 .{ }^{8}$ These SDGs have 169 associated targets, further elaborating on these SDGs. These Agenda 2030 indicators - the SDGs and their associated targets - guide the global community to act in partnership to end poverty and hunger, improve health and education, reduce inequality, spur economic growth, preserve natural resources and address climate change. ${ }^{9}$ The ultimate aim of sustainable development is that human societies can live and meet their material needs in such a way as to enable our future generations to survive and thrive as well. ${ }^{10}$

Sustainable development and actions for addressing climate change ('climate action') are closely related. Successful climate action would enable sustainable development by providing a stable and healthy planet climate setting. Otherwise, the adverse effects brought by climate change will aggravate poverty, undercut sustainable development and even endanger national security, especially in the Least Developed Countries ('LDCs'). Meanwhile,

5 Paris Agreement, supra note 1, art. 4.1. A $2^{\circ} \mathrm{C}$ temperature increase would reach critical heat tolerance thresholds for agriculture and health. A $1.5^{\circ} \mathrm{C}$ temperature increase would hit the tipping point for an irreversible change in the climate system, which locks in further global heating. See, Intergovernmental Panel on Climate Change, Climate Change 2021 - the Physical Science Basis, InTERgOVERnMENTAL PANEL ON Climate Change (August, 2021), https://www.ipcc.ch/report/ar6/wg1/\#FullReport.

6 Jen Christensen and Michael Nedelman, Climate Change Will Shrink US Economy and Kill Thousands, Government Report Warns, CNN (Nov. 26, 2018), https://www.cnn.com/2018/11/23/health/climate-change-report-bn/index.html. See also, Bill Gates, How to Avoid a Climate Disaster 20 (2121) (Crocodiles were living above the Arctic Circle during the age of the dinosaurs, where the average temperature was perhaps $4^{\circ} \mathrm{C}$ higher than today.)

Transforming our world: the 2030 Agenda for Sustainable Development, United Nations (October 21, 2015), http://www.un.org/ga/search/view_doc.asp?symbol=A/ RES/70/1\&Lang=E.

8 Ibid.

9 Sustainable Development Goals, United Nations (February 12, 2020), https:// sustainabledevelopment.un.org/?menu=1300.

10 Report of the World Commission on Environment and Development: Our Common Future, United NATiOns (March 1987), http://www.un-documents.net/our -common-future.pdf. The report was and is commonly called the Brundtland Report in recognition of former Norwegian Prime Minister Gro Harlem Brundtland's role as Chair of the World Commission on Environment and Development. 
sustainable development can decrease GHG emissions and thus reduce additional risks for climate change.

Clean technologies play a vital role in the global community's efforts to achieve the temperature goals and the net-zero emission target set in the Paris Agreement and enable sustainable development for the long term. In this book, cleantech refers to any technology that benefits the environment, contributes to sustainable development, or helps us mitigate or adapt to undesirable environmental conditions. The book uses the terms cleantech and 'clean technology' interchangeably; they are equivalent to or encompass terms such as 'sustainable technology,' 'green technology,' 'environmentally friendly/sound technology,' 'climate change technology,' and 'climate technology.' Cleantech is diverse, including a wide range of technology sectors and markets, such as agricultural, bioengineering, forestry, transportation, mechanical engineering, energy and information and communication technologies. ${ }^{11}$

Realizing the importance of cleantech for addressing climate change and building sustainable development, the global community has been searching for the optimal way to effectuate cleantech' s power globally. At the 15th UNFCCC Conference of the Parties ('COP'), ${ }^{12}$ which occurred in Copenhagen in December of 2009, UNFCCC member parties tried to negotiate a legally binding international agreement for addressing climate change. ${ }^{13}$ They had planned to include in the agreement provisions to enhance international cleantech transfer, particularly the transfer of cleantech from developed countries to developing countries. Unfortunately, the negotiation stalled. Developed countries and developing countries disagreed on a host of issues, especially the treatment of intellectual property rights ('IPR') protecting clean technologies. ${ }^{14}$ Even before COP 15 , developing countries proposed to exclude clean technologies, which are owned mainly by developed countries, from patent

11 Chapter 2 of this book contains a detailed discussion on cleantech; there, the reader can find enumerations of exemplary clean technologies.

12 The UNFCCC Conference of the Parties (COP) is the annual gathering of representatives from all 197 member states of the UNFCCC and is the top decision-making body for affairs concerning the UNFCCC. The conferences are usually named by the sequence number; for example, the 15 th COP is called COP 15. See, Conference of the Parties (COP), UNFCCC (November 19, 2020), https://unfccc.int/process/bodies/ supreme-bodies/conference-of-the-parties-cop.

13 Copenhagen Climate Change Conference-December 2009, UNFCCC (January 17, 2020), http://unfccc.int/meetings/copenhagen_dec_2009/meeting/6295.php.

14 Tove Iren S. Gerhardsen, Technology Transfer Will Be Part of Copenhagen Climate Deal, Intellectual Property Watch 3 (September 16, 2009), http://www.ip -watch.org/2009/09/16/technology-transfer-will-be-part-of-copenhagen-climate-deal/. 
protection..$^{15}$ Meanwhile, developed countries considered that cleantech IPR should not be part of the global climate change negotiations and proposed to remove provisions dealing with IPR from the negotiations. ${ }^{16}$

As it turned out, COP 15 produced a non-binding agreement. ${ }^{17}$ This agreement did not mention IPR issues, and developed countries pledged to provide USD100 billion per annum by 2020 to help developing countries address climate change. ${ }^{18}$ However, the debate regarding IPR persisted through the subsequent global climate change negotiations. In a later global climate change conference held in Lima in December 2014, both developed and developing countries proposed their positions regarding IPR as equal options to be presented during the following year's negotiation for the Paris Agreement. ${ }^{19}$ The disagreement on the treatment of cleantech IPR again became an issue stalling the discussion, which resumed only after removing IPR issues from the agenda. ${ }^{20}$ The same scenario occurred during the negotiation for the Paris Agreement - the negotiation stalled until the parties agreed to eliminate cleantech IPR issues from the negotiation agenda. The Paris Agreement's final language mentioned neither cleantech IPR nor the different positions on cleantech IPR held by developed and developing countries. Instead, as the quote at the beginning of this chapter shows, the Paris Agreement emphasizes the importance of innovation in addressing climate change and building sustainable development.

Concurrent to the happenings in the UNFCCC forum, similar tension emerged in the World Trade Organization ('WTO'). During 2013-2014, the Council for the WTO TRIPS Agreement ('TRIPS Council') $)^{21}$ organized five

15 Report of the Ad Hoc Working Group on Long-term Cooperative Action under the Convention on its seventh session, held in Bangkok from 28 September to 9 October 2009 and in Barcelona from 2 to 6 November 2009, UNFCCC 156 (November 20, 2009), http://unfccc.int/resource/docs/2009/awglca7/eng/14.pdf.

${ }_{16}$ Hira Jhamtani, Technology: US proposal to remove IPRs from the table arouses developing countries' objections, TEBTEBBA (August 11, 2009), http://www.tebtebba .org/index.php/content/137-technology-us-proposal-to-remove-IPR-from-the-table -arouses-developing-countries-objections.

17 Copenhagen Climate Change Conference-December 2009, supra note 13.

18 Tove Iren S. Gerhardsen, supra note 14.

19 Lima call for climate action, UNFCCC (January 17, 2020), http://unfccc .int/files/meetings/lima_dec_2014/application/pdf/auv_cop20_lima_call_for_climate action.pdf.

20 Per conversation with Dr. Bassem Awad, who was an observer at the conference.

${ }^{21}$ The Council for WTO TRIPS Agreement is the body that is responsible for administering the TRIPS Agreement; it is open to all members of the WTO. See, Council for TRIPS, World Trade Organization (March 19, 2020), https://www.wto.org/ english/tratop_e/trips_e/intel6_e.htm [hereinafter 'TRIPS Council']. 
meetings discussing the relationship between IP and climate change. ${ }^{22}$ Ecuador submitted a proposal ('Ecuador's 2013 proposal') arguing that cleantech IPR could create a monopolistic situation leading to high prices and restricted knowledge transfer for clean technologies. ${ }^{23}$ Ecuador proposed excluding clean technologies from patentable subject matter, incorporating into the TRIPS Agreement a new provision on the transfer of expertise or know-how, implementing compulsory licensing and reducing patent terms on clean technologies. ${ }^{24}$

Several developing countries such as Bangladesh, Bolivia, Brazil, China, Cuba, India, Indonesia, Nepal, Rwanda and the Dominican Republic supported Ecuador's 2013 proposal. ${ }^{25}$ India strongly supported the proposal's stand regarding compulsory licensing and reduction of cleantech patents' life terms. India stated:

On the principle of equity, the industrialized countries have to bear a large share of the burden. They are historically responsible for the bulk of the accumulated GHG emissions, and this alone suggests a greater responsibility. They also have high per capita incomes, which give them the highest capacity to bear the burden. They are technically the most advanced and to that extent best placed to provide environmentally sound technology to the developing countries at fair and favorable terms and conditions. ${ }^{26}$

India's statement captured developing countries' essential view on IPR's role in cleantech development and transfer. This view focuses primarily on access to cleantech.

Developed countries such as the United States ('US'), the European Union ('EU'), Japan, Canada, Switzerland, Australia and New Zealand countered that IPR instead encouraged cleantech development and transfer at an accessible price. The EU's response to Ecuador's proposal pointed out that many critical clean technologies were already in the public domain. It stated that

22 Climate Change and TRIPS, World Trade Organization (March 19, 2020), https://www.wto.org/english/tratop_e/trips_e/cchange_e.htm.

23 Contribution of Intellectual Property to Facilitating the Transfer of Environmentally Rational Technology-Communication from Ecuador, IP/C/W/585, World Trade Organization (February 27, 2013), https://docs.wto.org/dol2fe/ Pages/FE_Search/FE_S_S009-DP.aspx?language $=$ E\&CatalogueIdList $=115118 \&$ Cur rentCatalogueIdIndex $=0 \&$ FullTextSearch $=$ (hereinafter 'Ecuador 2013 proposal').

24 Ibid., at 4.

25 Extract from Minutes of Meeting of the Council for Trade-related Aspects of Intellectual Property Rights, Held on 11-12 June 2013, World Trade Organization 32 (June 2013), https://www.wto.org/english/tratop_e/trips_e/june2013_on_climate_e .pdf.

26 Ibid. 
the LDCs offered market values too small to attract commercial businesses from developed countries, and the LDCs could use foreign clean technologies for free as the LDCs generally do not provide IPR. ${ }^{27}$ Further, the EU argued that companies in developed countries owning clean technologies might be reluctant to engage in cleantech transfer and associated investments when the recipient countries did not provide patent protection for their products and processes. ${ }^{28}$ The EU stated: 'IPR, particularly patents, will be a catalyst, not a barrier, to creating and deploying low-carbon technologies.... Threats to strong IPR, such as easily obtained compulsory licensing, are likely to be a strong disincentive to invest. ${ }^{29}$

The EU's statements reflect developed countries' essential view on IPR's role in cleantech development and deployment. This view looks at IPR's impact on investments for cleantech development and deployment while emphasizing the importance of cleantech development.

Hence, we experience an ongoing divide between developing and developed countries regarding the role of IPR in the international transfer of clean technologies for addressing climate change and building sustainable development. ${ }^{30}$

This book explores whether the existence of IPR is a significant barrier to the international cleantech transfer and the possible reasons behind the currently limited transfer of clean technologies to developing countries. After analyzing evidential data available on clean technologies, the author concludes that IPR is not likely to become a significant barrier to the international transfer of clean technologies. The author considers developing countries' proposals to weaken or remove IPR for cleantech challenging to implement. Most of the proposals require amendments to the TRIPS Agreement and national legislative actions. Implementation of these proposals may also be counterproductive for enhancing international cleantech transfer, at least through the formal channels such as international trade, foreign direct investment and technology or IP licensing, which tend to favour countries with adequate IP protection. It is true that these proposals, when implemented, may enhance informal cleantech transfer

27 Ibid. at 40.

28 Ibid. at 41.

29 Ibid. (Quoting Ian Harvey, Intellectual Property Rights: The Catalyst to Deliver Low Carbon Technologies, ReSEARCHGATE (November 20, 2020), https://www .researchgate.net/publication/265617011_Intellectual_Property_Rights_The_Catalyst _to_Deliver_Low_Carbon_Technologies).

${ }_{30} \overline{0}$ Such a divide regarding IPR also exists in the global community's effort in addressing other global issues; a typical example would be global health. Section 3.6.1 will examine IPR's role in cleantech development and deployment, including a comparison of cleantech IPR and pharmaceutical IPR and a discussion on the proposal made by India and South Africa in October 2020 to waive IPR on Covid-19 vaccine technologies. 
through imitation, reverse engineering, or cross-border personnel movements. However, these informal channels for cleantech transfer may bring in very limited, if any, know-how and capital investments necessary for implementing complex cleantech projects.

Meanwhile, the author suggests developing countries utilize venues in competition law to address restrictive conduct in cleantech transfer and available mechanisms in IP laws to enhance access to needed cleantech. Developing countries seem to have yet to utilize the competition law measure provided to them by the TRIPS Agreement for addressing anticompetitive IPR practices they encounter during international technology transfer.

The author further examines different analyses and scholarship to understand the possible reasons for limited cleantech transfer since the 1970s. The examination concludes that two simultaneous enhancements are necessary to improve international cleantech transfer. Developing countries must augment their capacities to attract, adapt and implement foreign cleantech; such capacities include providing adequate IP protection for clean technologies. Meanwhile, developed countries must boost their efforts to provide aid (such as technical and financial assistance) to help developing countries - especially the LDCs - build up such capacities.

In the meantime, the author suggests that the global community focuses on facilitating both cleantech development and transfer globally and locally within individual countries, instead of merely on international cleantech transfer to developing countries. In reality, we need significant breakthroughs in cleantech innovation for mitigating and adapting to climate change and for making cleantech viable alternatives to traditional high-carbon technologies. The UNFCCC, the leading global multilateral regime for addressing climate change, fully realizes the two needs. The UNFCCC emphasizes cleantech development and deployment (including application, diffusion and transfer) instead of just international cleantech transfer. Specifically, the UNFCCC commits its members to promote and cooperate with developing and deploying technologies, practices and processes relevant to addressing climate change. ${ }^{31}$ Further, the Paris Agreement, the latest major milestone accomplished by the UNFCCC, states that the contracting parties 'share a long-term vision on the importance of fully realizing technology development and transfer' to respond to climate change and reduce GHG emissions. ${ }^{32}$

All countries need cleantech to address climate change in the near future and build sustainable development for the long term. Also, cleantech needs to

31 United Nations, United Nations Framework for Climate Change Convention, art.

4.1.C; UNFCCC (1992), https://unfccc.int/resource/docs/convkp/conveng.pdf.

32 Paris Agreement, supra note 1, art. 10.1-4. 
adapt to local climatic and ecological conditions. Therefore, the author suggests that all countries develop domestic cleantech innovation wherever possible. The author proposes a viable pathway for developing countries to move toward domestic cleantech innovation. The pathway contains three phases: international aid, mutually beneficial international cleantech cooperation and domestic cleantech innovation. A country can emphasize one or more of the three phases simultaneously, depending on its current capacity for domestic cleantech innovation.

The author suggests the global community supports developing countries in establishing their domestic cleantech innovation systems. Such purposeful support may come in the forms of international aid and mutually beneficial international cleantech cooperation. International aid enables developing countries such as the LDCs to survive climate change impact and build essential capacities for cleantech importation and cleantech innovation. Mutually beneficial international cleantech cooperation helps developing countries that have acquired such essential capacities to learn from advanced technologies and practices and move further toward domestic cleantech innovation.

For domestic cleantech innovation, the author suggests that governments purposefully engage in structuring cleantech industries and growing a green economy based on the countries' comparative advantages. In principle, a country's government should at least send consistent and clear policy signals to its private sector to indicate the government's long-term commitment to cleantech innovation. The author further suggests that the government leverages diverse innovation tools, including customized IP regimes for cleantech and non-IPR tools such as prizes, innovation commons and competition law and policy to foster cleantech innovation.

The book proceeds as follows. In the next chapter, we will review key concepts for the book, including the global community, climate change, sustainable development, clean technology and their relationships.

Part I focuses on international cleantech transfer. It explores whether IPR is a significant barrier to international cleantech transfer to developing countries and the reasons for the currently limited international cleantech transfer to developing countries. It then assesses IPR's necessary role in international cleantech transfer and what it takes to enhance international cleantech transfer. Part I concludes by suggesting developing countries leverage existing mechanisms available in the competition law regime and IP law regime and enhance local capacities to improve access to foreign cleantech. Such leverage can occur at least in parallel with the efforts, as exemplified by Ecuador's 2013 proposal, to reform the established and negotiated multilateral IP instruments.

Part II then focuses on global cleantech development. Here, we will illustrate the necessity of global cleantech development and its current reality. We will explore why we need to encourage domestic cleantech development 
whenever possible and what it takes to build domestic cleantech innovation. We then examine the reality of domestic cleantech innovation using data provided by global surveys. The discussion here highlights several developed and developing countries' recent performances on domestic cleantech innovation for illustration purposes. The examination observes that developing countries need to improve general or cleantech-specific innovation capabilities or both.

Based on the analysis in Part I and Part II, the author proposes a solution in Part III for enabling global cleantech development and international cleantech transfer. The proposal aims to build domestic cleantech innovation wherever possible. The proposal does suggest that countries construct their domestic cleantech innovation systems according to their specific strengths and circumstances. Part III details the pathway mentioned above and the relationships of the three phases in the pathway. Part III concludes by discussing the advantages and concerns regarding the implementation of the proposal.

This book is the first to propose and detail a pathway for developing countries to become capable of domestic cleantech innovation. This proposal aims to free developing countries from dependency on foreign cleantech where possible and secure them for modern economies and sustainable development. It is a sincere and thoughtful effort to drastically improve the limited international cleantech transfer to developing countries since the 1970s. The book acknowledges the necessary role of IPR in essential cleantech breakthroughs and international cleantech transfer. It also highlights the importance and long-term presence of mutually beneficial international cooperation for the needed global cleantech development and deployment.

Ultimately, the book envisions global cleantech development and deployment and international cooperation as crucial means to address climate change and secure sustainable development, hence, a sustainable future for us on the planet earth. The book is for use by policymakers and scholars in sustainable development, climate change, cleantech development and international cleantech transfer. It is also for the general public to engage with these topics. 